\title{
Türkiye'de İller Arası Göçlerde İkincil Göç Çekim Merkezleri ve Etki Sahalarının Tespiti
}

\section{Determining Secondary Migration Attraction Centers in Interprovincial Migrations in Turkey and their Impact Areas}

\author{
Fatih ARICI' ${ }^{1}$ \\ 'Arş. Gör. Dr., Sakarya Üniversitesi, Fen Edebiyat Fakültesi, Coğrafya Bölümü, Sakarya, Türkiye
}

ORCID: F.A. 0000-0002-8274-5844

\section{öz}

Bu çalışmada Türkiye'de iller arası göçler ele alınmış, net göç alan merkezler dışında göç alma potansiyeli bulunan ikincil göç merkezleri tespit edilmeye çalışılmıştır. Çoğunluğu göç veren toplam 47 il üzerine yürütülen çalışmada, bu merkezler arasından 9 ilin ikincil göç merkezi olarak yakın çevreden göç alma potansiyeline sahip olduğu tespit edilmiştir. Bu ikincil göç merkezlerinin etki sahalarının belirlenmesine ilaveten, göç almalarında etkili olan faktörlerin tespiti de yapılmıştır. Merkezlerin aldıkları mevcut göçler üzerinde ise sosyo-ekonomik gelişmişlikten daha çok, çevresindeki illere göre daha fazla kentleşme göstermeleri, yakın konumda bulunmaları ile kurulan sosyal ağlarla alakalı olduğu verisine ulaşılmıştır. Çalışmada ikincil göç merkezlerinin tespitinde; SEGE değerleri ile illerin cazibe katsayıları veri setlerinden faydalanılmıştır. Bu merkezlerin aldıkları göçler üzerinde etkili olan faktörlerin tespitinde ise illerde yaşam endeksi verileri kullanılmıştır. Analizlerde SPSS 22 paket programı, haritaların hazırlanmasında ise ArcGIS 10.2 programı kullanılmıştır.

Anahtar kelimeler: IIller arası göç, İkincil göç merkezleri, Göç etki sahası

\section{ABSTRACT}

The study discusses interprovincial migrations in Turkey and determines secondary migration centers that have the potential to receive migration other than those that directly receive migration. The researcher focused on 47 provinces, most of which are emigration centers. It was determined that nine of them had the potential of receiving migration from their immediate vicinity as a secondary migration center. In addition to determining factors that affect these centers in terms of receiving migration, the researcher tried to identify their impact areas. Furthermore, results indicate that rather than socioeconomic development levels, higher levels of urbanization compared with neighboring provinces and social networks established because of proximity were main factors for the migrations that these secondary migration attraction centers received. Socioeconomic development index (SEDI) values and attraction coefficients of provinces data were used to determine the centers in the study. Further, life index in provinces data were used to determine effective factors that influence migrations received by these centers. The SPSS 22 package program was used for data analysis, whereas the ArcGIS 10.2 program was used for preparing maps.

Keywords: Interprovincial migration, Secondary migration centers, Migration impact area

Başvuru/Submitted: 30.09.2020 • Revizyon Talebi/Revision Requested: 14.03.2021 • Son Revizyon/Last Revision Received: 26.04 .2021 • Kabul/Accepted: 26.05.2021 • Online Yayın/Published Online: 17.06.2021

Sorumlu yazar/Corresponding author: Fatih ARICI / farici@sakarya.edu.tr Atıf/Citation: Arici, F. (2021). Türkiye'de iller arası göçlerde ikincil göç çekim merkezleri ve etki sahalarının tespiti. Cografya Dergisi, 42, 195-209. https://doi.org/10.26650/JGEOG2021-802963 


\section{EXTENDED ABSTRACT}

Migration is an important global phenomenon for both developed and developing countries. Because of economic, social, and historical reasons as well as its geographic position, Turkey has received migrations throughout history. Population movements in the forms of international, domestic, transit, exchange, and refugee migrations are among important social phenomena for the country. The scope of the study is limited to interprovincial migrations. The literature review shows a large number of studies on this issue. In these studies, topics such as the sources and target of migration, the direction of migration, and factors affecting migration have been investigated. In this study, rather than the main destinations in interprovincial migrations, the researcher chose topics such as determining the secondary target provinces and impact areas of these provinces.

The direction of migration and the centers receiving migration in Turkey have not changed in the process. This situation causes changes in the regional distribution of the country's population and increases the developmental difference between regions. It also leads to economic, sociocultural, and environmental changes in provinces that both receive and send migrants. Therefore, it is important to determine secondary migration centers in migration-sending regions to keep migration under control.

In line with this purpose, 47 provinces were included in the study, most of which were sending migrants. Among these provinces the ones that may serve as secondary migration centers were identified. The literature indicates that several factors affect a place's potential to become a migration attraction center. The socioeconomic opportunities of provinces and distance of the migration were among the most dominant factors. Accordingly, SEDI values of provinces in terms of socioeconomic opportunities were used in determining centers. As for the distance component, attraction coefficients of provinces index scores were used. To see whether such datasets were statistically explanatory in terms of migrations, scale averages were computed and analyzed. After using the SPSS program for regression analysis, the result indicated a strong correlation between migrations and this dataset. It was concluded that the variable explained the migration values of the provinces that were statistically significant at a 0.01 level. Based on this result, this dataset was used to determine migration attraction centers. Provinces with high scale average in this dataset and those that received migrants from their surroundings were assumed to be migration attraction centers. Accordingly, 9 out of 47 provinces, namely, Konya, Kayseri, Gaziantep, Samsun, Malatya, Diyarbakır, Van, Erzurum, and Trabzon, were determined at a local scale as secondary migration centers.

The impact areas of the provinces that were identified as secondary migration centers were also determined. In determining impact areas, Turkish Statistical Institute's (TSI/TUIK) data regarding interprovincial migration were used. The examination of this dataset revealed the centers mostly receive migration from the neighboring provinces as secondary migration centers.

In the last part of the study, factors that were statistically significant in terms of centers receiving migration were determined. The researcher used a total of 16 variables consisting of SEDI index scores; life index values in provinces; demographic characteristics; and education, health, urbanization, security, and economic factors, which were determined to have a statistically significant effect on the migrations received by the provinces, as observed in previous studies.

According to the results of the analysis, while SEDI values explained $25 \%$ of the received migrations, attraction coefficients of provinces data explained $71 \%$ of the migrations, which was calculated using population and distance. Based on the analysis of the life index in provinces values obtained from TSI, a positive and significant relationship existed between the social life index of the provinces and the migrations they received. These results indicate that urbanization and proximity in kilometers are more effective factors in terms of received migrations than the socioeconomic conditions of the provinces that serve as secondary migration centers. Another analysis was made to identify factors contributing to the increase of secondary centers' potential of receiving migration. The result of such an analysis suggests that factors such as employment, industrialization, number of teachers, hospital opportunities, population, and urbanization level had a positive, strong, and significant relationship with migrations at significance levels of 0.05 and 0.01 . The development of these factors will increase the potential of these centers to become attraction centers for migration, which will lead to an increase in the share of these centers in migrations that originate from their surroundings. On another note, such a situation will mitigate the pressure on provinces that continuously receive migration and decrease problems that stem from migrations. 


\section{GİRIŞ}

Göç, genel manada kalıcı veya belirli bir süre için yapılan ikamet değişikliği olarak tanımlanmaktadır (Lee, 1966, s. 49). Bu ikamet değişikliğindeki amaç daha iyi bir yaşam beklentisidir (Ünal, 2020, s. 195). İlk bakışta basit bir yer değiştirme olayı gibi görünse de, bu sosyal olgu; nedenleri ve sonuçları bakımından, toplum ve bireyler üzerinde önemli etkilere sahiptir (Bülbül ve Köse, 2010, s. 76). Bu sebeple, toplumsal değişmenin hem ürünü hem de önemli bir göstergesi olan göç olgusunun analizi, toplumu anlama ve açıklama çabasındaki disiplinler için önemli bir faktör durumundadır (Erdoğan, 2019, s. 17-18). Özellikle kentleşme ve bölgesel eşitsizlik gibi faktörlerle yakından ilişkili olan göç olgusunun altında yatan sebepleri ve diğer aktörlerle olan karşıllklı ilişkilerini anlama girişimi kalkınma dinamikleri bağlamında ülkeler için önem taşımaktadır (Kundu ve Gupta, 1996, s. 3397). Bu doğrultuda, göçü anlamak ve açıklamak için çeşitli teoriler, kavramsal ve istatistiksel modeller geliştirilmiştir (Walters, 2000, s. 119) Göçlerle ilgili ilk sistematik teori: 19. yüzyılda istatistiksel göç yasalarını formüle eden coğrafyacı Ravenstein'ine aittir (Castles ve Miller, 1998, s. 20).

Genel olarak insanları göçe iten sebepleri; ekonomik, siyasal, çevresel ve kültürel başlıklar altında toplamak mümkündür (Tümertekin ve Özgüç, 2015, s. 295). Bu genel nedenlere, kişisel talepler ve zorunlu yer değiştirmelerde ilave edilebilir (Özgür, 2001, s. 126). İster gelişmiş, ister gelişmekte olsun, dünyanın hemen her ülkesi yukarıdaki nedenlere bağlı olarak; iller, bölgeler veya ülkeler arası göç olgusunu yaşanmaktadır (Tümertekin ve Özgüç, 2015, s. 318). Dinamik bir yapıya bağlı olarak meydana gelen bu değişimler ve ortaya çıkan yeni sürecin anlamlandırılması ve değerlendirilmesi önümüzdeki dönemlerde daha da önemli olacaktır (Massey vd., 1993, s. 463). Çünkü ülkeler ve bölgeler arası gelişmişlik farkları, siyasal ve güvenlik sorunları, iç karışıklıklar ile savaşlar varlığını koruduğu müddetçe bu olgunun devam etmesi kaçınılmaz olacaktır.

Küresel bir olgu olarak tarihin her döneminde önemini koruyan göç, Türkiye açısından da gerek Cumhuriyet öncesi ve gerekse Cumhuriyet döneminde önemli toplumsal olgulardan biri olmuş ve olmaya devam etmektedir. Dış göçler; transit göçler, mübadele göçleri ve mülteci göçleri ile ülke içerisinde cereyan eden nüfus hareketlerinin tarih boyunca bu topraklarda sürekli yaşandığı görülür. Geniş boyutlu bir yapıya sahip olan göçler, çalışmanın amacı doğrultusunda Türkiye'deki iller arası göçlerle sınırlı olarak ele alınmıştır.
Türkiye'de 1950'de daha çok kırdan kente şeklinde başlayan iç göçlerin ivme kazanmasında; ulaşım ve haberleşme imkânlarının artması, tarım dışı sektörlerin gelişimi ve hemşericilik ilişkileri etkili olmuştur (Özgür, 2001, s. 126). Kırsal kesimde karşılaşılan sosyo-ekonomik zorluklar ise kırdan olan göçleri kolaylaştırmıştır (Koday, Koday ve Akbaş, 2018, s. 540). 1975-1980 dönemine kadar daha çok kırdan kente olan göçler, bu dönemden sonra azalmaya başlamış, kentten kente göçler ise artış göstermiștir (Kocaman, 2008, s. 62). Daha çok kırsal alanların iticiliği ile başlayan iç göçler, 1990 ve sonrasında ise kentlerin çekiciliği ile daha da hızlanmıștır. Geçmișe nazaran artarak devam eden bu hareketlilik, nedenleri ve sonuçları itibari ile ülkemizde birçok sosyal ve ekonomik soruna kaynaklık etmektedir. Toplumsal sorunlar içerisinde önemli bir konumda bulunması çok sayıda araştırmaya konu olmasına neden olmuştur.

Geniş ve çok boyutlu bir yapıya sahip olması sebebiyle de; coğrafya, sosyoloji, demografya, tarih, siyaset bilimi ve iktisat gibi birçok disiplin tarafından farklı yönleri ile ele alınarak araştırılmasını zorunlu kılmıştır (Aydoğdu ve Bakırcı, 2020, s. 3). Yapılan çalışmalarda iç ve dış göçler ele alınarak Türkiye özelinde değerlendirmelerde bulunulmuştur. $\mathrm{Bu}$ araştırmalar içerisinde çalışma konumuzu da oluşturan iç göçler ise gerek yerel, gerekse bölgesel ve ulusal boyutta çok sayıda teorik ve istatistiksel çalışmayla ele alındığı görülür. Türkiye'de iç göçleri etkileyen faktörleri istatistiksel modellerle ele alarak inceleyen bu çalışmalarda net göçler üzerinde; istihdam, gelir, nüfus artış hızı, illerin gelişmiş̧lik değerleri, eğitim, sağlık, alt yapı olanakları vb. gibi faktörlerin etkili olduğu sonucuna ulaşı1mıştır (Çelik, 2006; Gürbüz ve Karabulut, 2007; Yakar, 2013; Dücan, 2016; Albayrak ve Abdioğlu, 2017).

\section{AMAÇ VE YÖNTEM}

Türkiye'de iller arası göçleri konu edinen bu çalışmalarda; göçün kaynak ve hedef noktaları, göç yönü ve göçün kümelendiği merkezlerin belirlenmesi yanı sıra göç üzerinde etkili olan faktörlerin tespiti vb. ele alınan konuları oluşturmaktadır. $\mathrm{Bu}$ çalışmada ise iller arası göçlerdeki asıl hedef noktalarından ziyade ikincil hedef iller ve bu illerin etki sahaları ile göç almalarında etkili olan faktörlerin tespiti araştırma konusu olarak belirlenmiştir. Çalışmanın bu yönü ile literatüre katkı sunması umulmaktadır.

Türkiye'de göç olayının tarihsel gelişimi irdelendiğinde, göç yönü ve göç alan merkezlerin genelde değişmediği görülür. $\mathrm{Bu}$ durum ülke nüfusunun bölgesel dağılımına, bölgeler arası gelişmişlik farkının artmasına, hem göç alan, hem de göç veren illerde ise; ekonomik, sosyo-kültürel ve çevreye dayalı 
değişimlere neden olmaktadır. Bu sebeple, göç veren bölgelerde alternatif göç hedeflerinin yani ikincil göç merkezlerinin belirlenmesi önem taşımaktadır. $\mathrm{Bu}$ türden göç çekim merkezlerinin belirlenmesi ve gelişiminin sağlanması, bu sosyal olgunun kontrol edilebilmesine katkı sağlayacaktır. Çünkü göç veren bölge illerinden kaynaklanan bu hareketin önemli bir kısmının yine bölge içerisindeki bu ikincil göç merkezlerinde sonlanacaktır. $\mathrm{Bu}$ sonuç ise; ülke genelinde nüfusun dengeli dağılımına, kaynakların ve yatırımların ise bu doğrultuda daha doğru kullanımına dolayısıyla bölgesel eşitsizliğin azaltılmasına fayda sağlayacaktır.

Çalışma bu amaç doğrultusunda çoğunluğu göç veren 47 ili kapsayacak şekilde yürütülmüştür. Bu iller arasından, ikinci derece göç ağları ve hedef merkezleri olabilecek 9 göç çekim merkezi tespit edilmiştir. Göç çekim merkezlerinin tespitinde illere ait "SEGE" değerleri ile yine "illerin cazibe katsayıları" endeks puanlarının ortalamaları kullanılmıştır. $\mathrm{Bu}$ veri setinin tercih edilmesinde daha önceki çalışmalar dikkate alınmıştır. Çünkü literatürde bir merkezin göç çekim merkezi olabilmesinde birçok faktörün etkili olduğu, ancak en baskın faktörlerin illerin sosyo-ekonomik imkânları ile göç mesafesi olduğuna vurgu yapılmaktadır. $\mathrm{Bu}$ doğrultuda illerin sosyo-ekonomik gelişmişliğini yansıtan "SEGE" değerleri ile illerin nüfus ve mesafe verisini barındıran "illerin cazibe katsayıları" veri seti tercih edilmiştir. "İllerin ve Bölgelerin Sosyo-Ekonomik Gelişmişlik Sıralaması Araştırması (SEGE)" endeks değerleri Sanayi ve Teknoloji Bakanlığı (2019), illerin cazibe katsayıları ise Bindak (2015)'ten temin edilmiştir. Merkezlerin etki sahalarının tespitinde de TÜİK iller arası göç verileri kullanılmıştır.
Çalı̧̧manın son bölümünde ise bu merkezlerin göç almasında istatistiksel olarak anlamlı olan faktörlerin tespiti yapılmaya çalışılmıştır. Bu faktörlerin tespitinde önceki çalışmalarda illerin aldıkları göçler üzerinde istatistiksel olarak anlamlı etkisi olduğu test edilen; "SEGE" endeks puanları, "illerde yaşam endeksi değerleri" ile demografik, eğitim, sağlık, kentleşme, ulaşım, asayiş ve ekonomik faktörlerden oluşan toplam 16 değişken kullanılmıştır. $\mathrm{Bu}$ veri setlerine dayalı analizler yapılarak sonuçlar raporlanmıştır. İllerin göç almasında etkili olan faktörlerin belirlenmesindeki amaç, ikincil göç çekim merkezlerinin geliştirilmesi adına uygulanacak; ekonomik ve sosyal kalkınma kararlarına öneri olarak katkıda bulunmaktır. Göç çekim merkezlerinin tespiti ve illerin mevcutta aldığı göçler üzerinde etkili olan faktörler, SPSS 22 paket programında regresyon ve korelasyon analizleri ile tespit edilmeye çalışılmıştır. Çalışmada ihtiyaç duyulan haritalar ise ArcGIS 10.2 paket programı kullanılarak hazırlanmıştır.

\section{BULGULAR}

\subsection{Türkiye'de İller Arası Göçler: Kaynak ve Hedef İller}

Türkiye'de, 1935 yılında doğdukları il dışında yaşayanların yani göç etmiş nüfus olarak kabul edilenlerin oranı $\% 6,8$ 'dir. Bu göç eden nüfusun \%64,2'si İstanbul, Ankara ve İzmir'de yaşamaktadır (Tümertekin ve Özgüç, 1997, s. 237). 2000 y1lı verilerine göre ise nüfusun \%27,8'i doğduğu ilin dışında yaşamaktadır (Kocaman, 2008, s. 59). 2019 yılı verilerine göre de nüfusun \%33,8'i yani üçte biri doğduğu ilin dışında ikamet etmektedir.

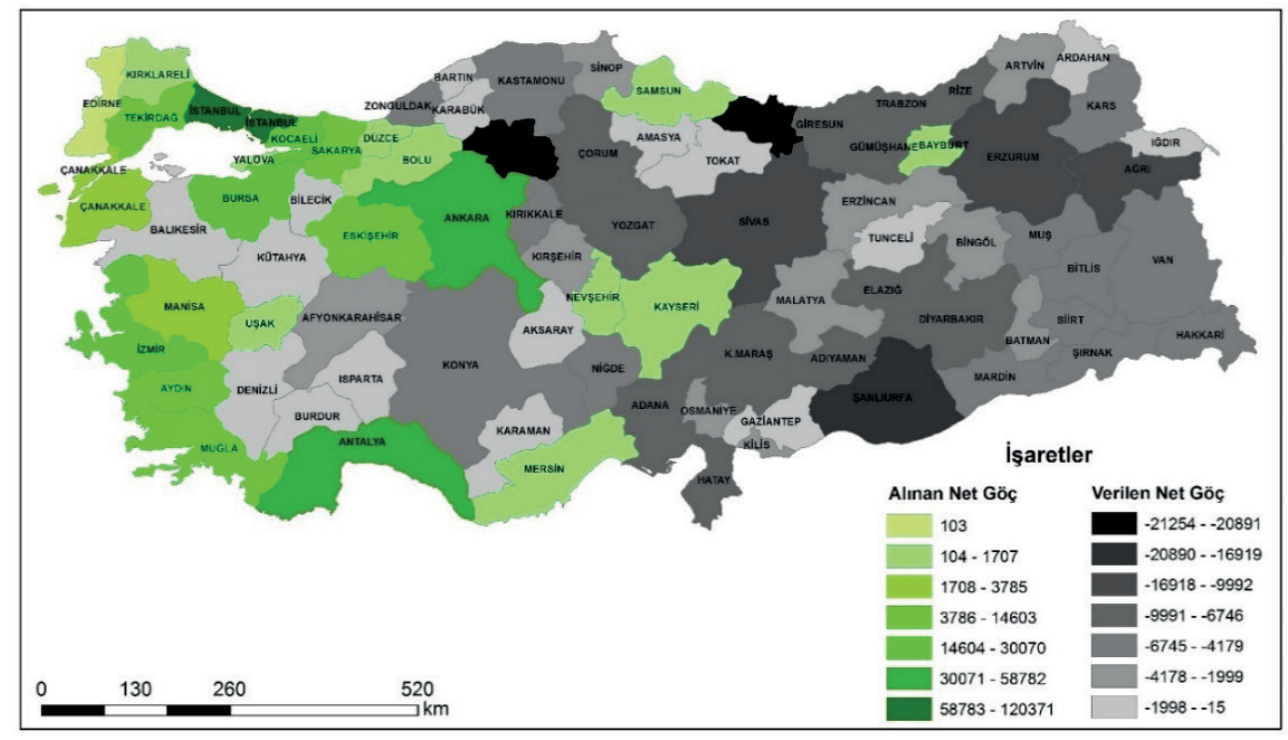

Şekil 1: 2019 Yılında İllere Göre Alınan ve Gönderilen Net Göç Değerleri (kişi).

Figure 1: Net Received and Sent Migration Values in 2019 by Provinces (person). 
2019 yılı TÜİK iller arası göç verilerine göre, Türkiye'de 81 ilin 24'ünün net göç miktarı pozitif yani aldığı göç verdiği göçten fazla iken, geri kalan iller negatif yönde bir durum sergilemişlerdir (Şekil 1). Net göç miktarı pozitif olan merkezler arasında; en yüksek göç oranına sahip olan ilin \%38,08 oranıyla İstanbul olduğu görülür. $\mathrm{Bu}$ çekim merkezini sırasılyla Ankara $(\% 18,12)$, Antalya $(\% 10,01)$ ve İzmir $(\% 6,79)$ gibi iller izlemektedir. Türkiye'de son yllda meydana gelen göçlerin \% 73 'ü bu dört merkeze gerçekleşmiştir. Bu illeri takip eden; Bursa, Kocaeli ve Tekirdağ'a olan net göçlerde hesaba katıldığında toplam net göçün \%87,34'ü gibi oldukça yüksek bir değerinin sadece bu yedi ile gerçekleştiği görülür.

Türkiye'de kabaca Bartın-Adana hattının doğusundaki iller ile batısındaki iller arasında ciddi sosyo-ekonomik dengesizlikler bulunmaktadır. $\mathrm{Bu}$ farklılık, ekonomik ve sosyal firsat eşitsizliğini doğurmakta ve iller arası göç olayını hızlandırmaktadır. Genel olarak bu hattın doğu tarafındaki iller göç vermekte iken batı tarafındaki iller göç almaktadır (Gürbüz ve Karabulut, 2007, s. 476). Güncel göç verileri irdelendiğinde de bahsi geçen hattın doğusunda kalan illerin göç vermeye devam ettiği görülmektedir. Dolayısıyla, bölge ve iller arasındaki gelişmişlik farkı ülke içerisindeki coğrafi hareketliliğinin en önemli sebebini oluşturmaktadır.

Bölgelerarası ekonomik gelişmişlik farklarının süreç içerisinde büyüyerek devam etmesi ise, eskiden beri göç alan merkezlerin daha yoğun şekilde göç almalarına neden olmaktadır (Iş̧k, 2005, s. 58). Sosyo-ekonomik gelişmişlik farklarının tüm illere ve bölgelere dengeli yayılamaması günümüzde büyükşehir statüsüne sahip illerin bile göç vermesine neden olmaktadır. Çevresine göre daha gelişmiş merkez durumunda olan bu şehirlerin yarısının göç verdiği görülür (Şekil 1). Bu durum büyükşehir statüsüne sahip illerin aslında sosyo-ekonomik gelişmişlikten ziyade nüfus miktarı ile ön plana çıktı̆̆ını göstermektedir. Timor (1997), ülkemizde belirli merkezlerin göçlerle kısa sürede ve süratle nüfuslanmasının şehirleşme olayının demografik nitelik kazanmasına, dolayısıyla ülkemiz şehirlerinde özellikle de büyükşehirlerin sağlkklı bir şehirleşme gösterememesine neden olduğunu ifade etmektedir (s.99). Benzer şekilde, Arınç (2016), Güneydoğu Anadolu Bölgesi kentsel yerleşmelerinden bahsederken, sanayileşmeye bağlı şehirleşme sürecini nispeten Gaziantep ilinin sağladığını, bölgenin diğer illerinin ise bu yönde bir gelişim gösteremediğini ifade etmektedir (s. 297). Bu genellemeyi göç veren diğer büyükş̧ehirler için de yapmak yanlış olmayacaktır. Henüz istenilen gelişmeyi sağlayamamış olan, ancak çevresindeki illere; ticaret, eğitim ve sağlık alanlarında üst kademe merkezlik yapan, bölgesinde nispeten gelişmiş olan bu merkezlerinin göç çekiminde etkisiz kalması ise ulusal göç çekim merkezlerinin sürekli cereyan eden göçlerle gitgide kalabalıklaşmasına ve göçlere bağlı sorunların artış göstermesine neden olmaktadır.

Türkiye'de göçlerin yoğunlaştığı ulusal göç çekim merkezleri üzerine bir değerlendirme yapıldığında, tarihin her döneminde göç çekimi bakımından İstanbul'un ayrı bir yeri olduğu görülür. İlin son dönemlerde verdiği göç miktarı giderek artmakla birlikte, halen en fazla göç alan il konumundadır. Günümüzde gerçekleşen iç göçlerin \%38,08'inin yöneldiği İstanbul; 64 ilin en fazla göç verdiği, geri kalan 16 ilin ise ikinci surada en fazla göç verdiği merkez durumundadır. İstanbul'un yanı sıra Türkiye'de iller arası göçlerin kümelendiği diğer ulusal ölçekteki göç çekim merkezleri; Ankara, Antalya, İzmir, Kocaeli, Bursa ve Tekirdağ şeklinde sıralanabilir (Şekil 2).

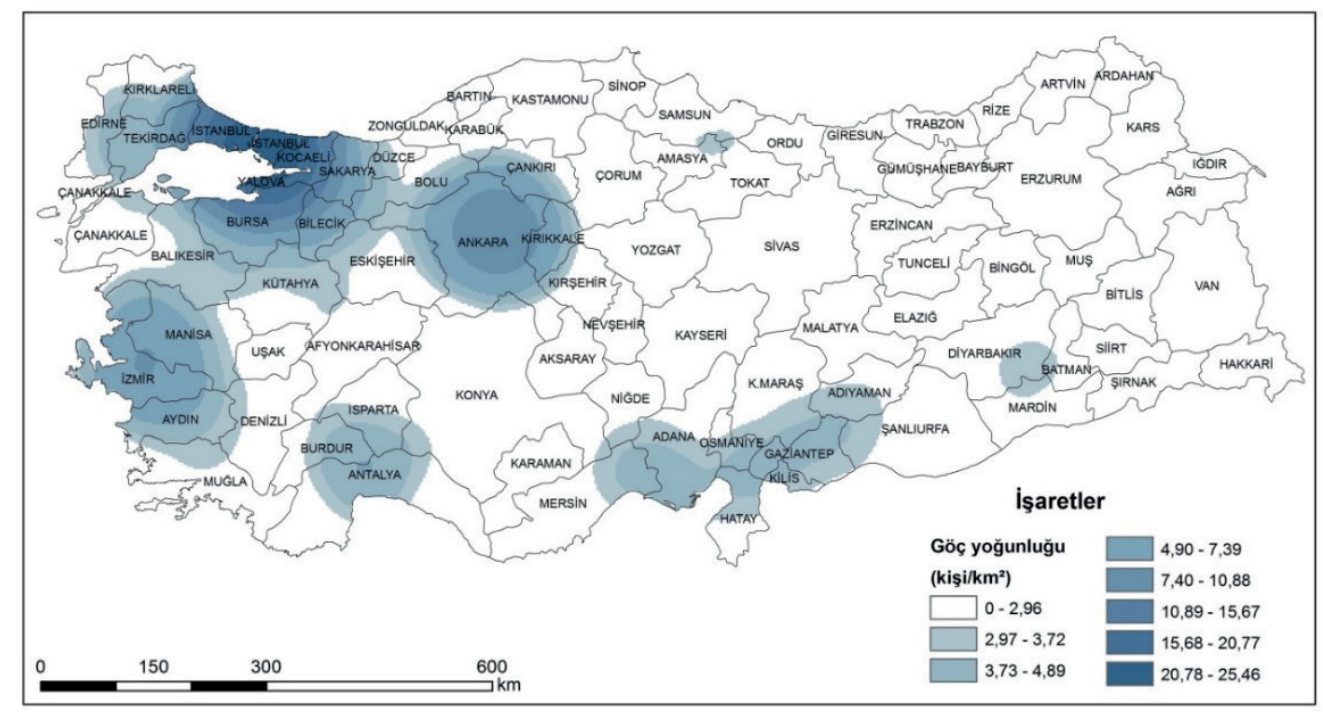

Şekil 2: Türkiye'de Göçlerin Yoğunlaştığı Alanlar.

Figure 2: Concentration Areas of Migration in Turkey. 
Ülkemizde meydana gelen göçlerde hedef noktalarının belli alanlarda yoğunlaşmasının sebebi iş ve istihdam imkânları bakımından diğer illere nazaran bu alanların ön plana çıkması ile alakalıdır. İş imkânlarının yani üretim ve istihdam olanaklarının büyük kısmının bu il gruplarında yer alması bu alanların sürekli göç çekim merkezleri olmalarına neden olmuştur.

Yaygın kullanılan göç kuramlarından, merkez-çevre kuramı; sosyo-ekonomik yönden gelişimini tamamlamış ve işgücü ihtiyacı olan merkez bölgeler için alınan göçlerin kalkınma üzerindeki olumlu yönde etkisi olacağını vurgulamaktadır (Çağlayan, 2006, s. 78-79). Ancak, gelişmekte olan bölgeler için işgücü ihtiyacından daha fazla gerçekleşen göçler; güvenlik, çevre, altyapı, ulaşım, eğitim, sağlık ve ekonomik yönden bir takım sorunları da beraberinde getirmektedir. Buna karşın göç veren bölgelerde de; nüfus miktarının azalmasına bağlı olarak yatırımların azalması, sektörel olarak işgücü kaybı gibi bir takım sorunlar ortaya çıkarmaktadır.

Geçmişten günümüze, dünyada göç olgusu için pek çok yeni motivasyon ortaya çıkmış olmasına rağmen, Türkiye gibi gelişmekte olan ülkeler için, istihdam yani ekonomik sebepler temel göç nedeni olarak yerini korumaya devam etmektedir (Öztürk, Topaloğlu, Hilton ve Jongerden, 2017, s. 528). Sanayileşme dolayısıyla gelişme çabasında olan ülkemiz kentleri ise, sanayileşme hızından daha yüksek bir oranla göç aldığından göçle gelen bu nüfusu istihdam edememektedir (İçduygu ve Sirkeci,1999, s. 252). Özellikle 1980'li yıllardan sonra hızlanan ve ülkemiz şehirlerin kaldırabileceği düzeyden daha fazla gerçekleşen göçler, şehirlerin makro (mekânsal) ve mikro (yaşam standartları, altyapı vb.) dengelerinin bozarak, şehirleşmenin nitelik ve kalitesinin düşmesine neden olmuştur (Sarı ve Kındap, 2018, s. 41). Bu durum ise Türkiye'de aşır1/ çarpık kentleşme ve buna bağlı kentsel sorunların yaşanmasına neden olmaktadır (Bostan, 2017, s. 14). Dolayısıyla ülkemiz kentleri arasındaki gelişmişlik farkları önemini korudukça da, bu hareketlilik aynı yönde devam edecektir.

Sonuç olarak kısa vadede Türkiye'de iller arası göçleri durdurma mümkün olmadığına göre, göçleri yönlendirici bir politikanın izlenmesi daha faydalı olacaktır. Bu da göç veren bölgelerdeki sanayi ve hizmet sektörlerinin yoğunluk kazandığı belirli merkezlerin desteklenerek geliştirilmesiyle mümkün olacaktır (Tandoğan, 1998, s. 91). Günümüzde bu görevi üstlenecek "bölgesel göç çekim merkezi" potansiyeline sahip kentler bulunmaktadır. Bu kentlerin sosyal, kültürel ve ekonomik bakımdan belirli bir düzeye ulaştırılması, bölgesel göçler için "cazibe merkezleri" olmalarını sağlayacaktır (Çelik, 2007, s.
103). 1960 sonrasında hazırlanmaya başlanan kalkınma planlarında da iç göç olgusunun önemine vurgu yapılarak, göçleri yönlendirme ve denetim altında tutmaya yönelik bazı öngörü ve planlama önerileri sunulmuştur. Göçleri denetim altında tutmak için de, ekonomik gelişmenin sağlanması, sanayi ve altyapının ülke geneline dengeli dağılımının öncelikli olarak ele alınmasına vurgu yapıldığı görülür. Örneğin, 6. Beş Yıllık Kalkınma Planı'nda; göçleri yönlendirme ve denetim altına alma adına yeni bir yerleşme kademelenmesinin yapılması öngörüsü yer almıştır (DPT, 1989). Benzer şekilde 8. Beş Yıllık Kalkınma Planı'nda; metropoliten alanlara yönelen göç yoğunluğunu azaltmak için, metropol altı ve orta büyüklükteki merkezlerin tespiti ile bölge içi göçlerin yönlendirilmesi gerekliliğine vurgu yapılmıştır (DPT, 2000).10. Kalkınma Planı'nda ise 2008 yılından itibaren ülkenin batısına yönelen göçlerin azaltılması adına, ülkenin orta ve doğusundaki bazı önemli şehirlerin çekim merkezine dönüştürülmesini amaçlayan "Cazibe Merkezlerini Destekleme Programı” uygulamasının başlatıldığına yer verilmektedir (Kalkınma Bakanlığı, 2013).

\subsection{Göç Veren Bölgelerde İkincil Göç Çekim Merkezlerinin Tespiti}

Çalışmada, kalkınma planları ve akademik yazında da önemine değinilen, ülkenin batısına yönelen göç yoğunluğunun azaltılması adına yerel veya bölgesel göç çekim potansiyeli olan ikinci kademe göç merkezlerinin tespitine odaklanılmıştır. $\mathrm{Bu}$ doğrultuda ikincil göç hedeflerinin tespiti için geneli göç veren bölge illeri üzerine yoğunlaşılmıştır. Bu illerinin uzun süreden beri göç veren illerden olmaları yapılan çalışmalarda göç alan/ veren iller hattı olarak tanımlanmalarına neden olmuştur. Mutluer, (2003); Gürbüz ve Karabulut (2007) ile Yakar ve Sert Eteman (2017) çalışmalarında; göç alan ve veren illerin ayrımında Zonguldak/Bartın-Adana hattını, Tandoğan (1998) ise yüksek oranda göç veren illerin yukarıda belirtilen hatta benzer şekilde Sinop-Anamur hattının doğusunda yer aldıklarını belirtmiştir. Çalışmaya vurgulanan bu hattın doğusundaki illeri kapsayacak şekilde başlanmış, süreç içerisinde çekim merkezleri ile etki sahalarının bütünlüğü esasına dayalı olarak, küçük bir değişiklikle Kastamonu-Antalya hattı belirlenmiştir.

2019 yılı TÜİK iller arası göç verilerine göre Türkiye'de 81 ilin 57'si net göç vermektedir. Net göç veren 57 ilin 44'ü Kastamonu-Antalya hattının doğusunda yani araştırmamıza konu olan iller arasında yer almaktadır. Türkiye'de iller arası göç verileri irdelendiğinde, hemen hemen tüm illerin belirli nedenlere bağlı olarak belli miktarlarda birbirlerine göç verip, almakta oldukları görülür. Bir ilin anlamlı miktarda göç alması yani 
çekim merkezi olmasında literatürde; kentleşme, sanayileşme ve diğer illere nispeten daha iyi imkânlara sahip olması gibi ilin sosyo-ekonomik ve kültürel gelişmişliğine vurgu yapılmaktadır.

Ayrıca, kentlerin sahip olduğu; kamusal hizmet şartları, eğitim, sağlık imkânları ve yaşam kalitesi ile ilgili bilgi akışı da göç kararlarını etkileyebilmektedir (Ghatak, Levine ve Price, 1996, s. 187). Göçün geleneksel açıklamaları, göç verilen bölgede iticiliğe buna karşın, göç alan bölgelerde ise çekiciliğe neden olan faktörler üzerine kuruludur. Yüksek gelir, istihdam, eğitim ve sağlık imkânları çekici; düşük gelir ve işsizlik gibi unsurlar ise itici faktörlerdendir. Bu faktörler literatürde "itici ve çekici güçler yaklaşımı" çerçevesinde incelenir (Çelik, 2006, s. 150). İtici ve çekici güçler yaklaşımının öncüleri Ravenstein ve Lee'dir. Ravenstein, 1885 ve 1889 'da yayınladığ “Göç Kanunları" çalışmasında, illeri özellikleri ve sahip olduğu imkânlara göre, göç veren (dağıtım) ve göç alan (çekim) olmak üzere iki gruba ayırmıştır (Abar, 2011, s. 14). İtici ve çekici güçler kuramını "Göç Teorisi (A Theory of Migration)" isimli çalışmasında formüle eden Lee (1966), ise çalışmasında; göç hareketinin ne kadar kısa veya uzun olursa olsun, her göç eyleminin çıkış, varış yeri ve mesafesinin bir dizi olumsuz unsur içerdiğini ifade etmektedir. Göçe karar aşamasında insanlar için her alanda itici ve çekici faktörlerin varlığına değinen Lee, bu faktörlerden bazılarının çoğu insanı aynı şekilde etkilerken, diğerlerinin ise farklı şekillerde etkilemekte olduğunu belirtmektedir (s. 49-50).

İtme-çekme kuramı sonraki yıllarda diğer araştırmacılar tarafindan yapılan katkılarla daha da gelişmiştir (Çağlayan, 2013, s. 93). Bu katkılardan biri Peterson'a aittir. W. Peterson 1958 yılında yayınladığı çalışmasında, itme ve çekme kuramına bireysel ve sosyal faktörleri de ilave etmiştir. Bireyleri göçe sevk eden nedenlerin sadece itici ve çekici faktörlerinden ibaret olmadığını, aynı zamanda bireysel ve sosyal faktörlerin de etkisinin olduğunu ifade etmiştir (Ela Özcan, 2017, s. 190). Göç hareketinin başlamasında veya göç hedef noktasına karar verilirken, gidilecek yer hakkında bilgi, iş bulma, uyum gibi kültürel ve sosyal sermayenin yani sosyal faktörlerin de önemine vurgu yapılmaktadır (Güllüpınar, 2012, s.78). Göçmeler arasında kurulan ağlar, sosyal sermayenin bir biçimini oluşturmaktadır. Kurulan bu ağlar; göç kaynaklı riskleri ve masrafları azaltarak göçleri artırıcı etkide bulunur (Massey vd., 1993, s. 448-449). Dolayısıyla, göçler üzerinde artırıcı etkiye sahip olan göçmen ilişkiler ağı, hedef alana olan göçleri; ekonomik yük ve sosyal uyum gibi olumsuz unsurları hafifleterek, teşvik edici yönde etki yapmaktadır (Çağlayan, 2006, s. 86). Bu dayanışma ağları, bireylerin göçe karar alma motivasyonlarını etkiledikleri gibi göçün devamlılı̆̆ını sağlayan önemli mekanizmalar olarak da karşımıza çıkmaktadır. Böylece sürece dâhil olacak yeni göçmenler için de bir yol haritası işlevi görmektedirler (Görgün, 2017, s. 1326).

Stouffer, (1940) ise nüfus hareketlerinin dağılımını belirlemek için itici, çekici ve sosyal faktörler yanı sıra mesafe faktörünün de analizlere dâhil edilmesi gerektiğini vurgulamaktadır. Stouffer'e göre, göçlerin dağılımında mesafenin nasıl işlediği dikkate alınmalıdır. Şikago'nun Iowa'dan kaynaklanan göçleri New York’tan daha fazla "çektiği" ve New York'un ise Massachusetts'ten göç edenleri Chicago'dan daha fazla "çektiği” göz önüne alındığında, analizlerde mesafe faktörünün önemi ortaya çıkmaktadır. $\mathrm{Bu}$ sebeple mesafe bileşeninin dâhil edilmediği, sadece itici ve çekici faktörlerin kullanıldığı analizler çok verimli sonuçlar vermeyecektir (s. 846).

Dolayısıyla kırsal alanlar için her zaman göç çekim merkezi olan kentlerin, kentten kente göç çekim gücü noktasında birçok unsurdan etkilendiği görülür. Araştırmamıza dâhil olan iller arasında ikincil göç çekim merkezi potansiyeline sahip olan illerin tespitinde, yukarıda vurgulanan kuramsal bakış açısına uygun olacak şekilde hem illerin sosyo-ekonomik imkânları, hem de göç mesafesi bileşeni doğrultusunda değerlendirme yapılmıştır. Göç etki sahaları ve bu merkezlerin aldığı göçler irdelenirken TÜİK göç verileri ve daha önceden kurulan sosyal ağlar dikkate alınmıştır. Değerlendirmede kullanılan veri setleri daha önceki çalışmalarda illerin aldığı göçlerde anlamlı etkisi vurgulanan illere ait "SEGE" puanları ile Bindak (2015) tarafindan hesaplanan “illerin cazibe katsayıları" oluşturmaktadır. $\mathrm{Bu}$ veri setlerinden ilki 81 ili kapsayan analiz neticesinde elde edilen SEGE-2017 endeks değerlerinden oluşmaktadır. Bu endeks değerleri, Sanayi ve Teknoloji Bakanlığı Kalkınma Ajansları Genel Müdürlüğü tarafından hazırlanmıştır. "IIllerin ve Bölgelerin Sosyo-Ekonomik Gelişmişlik Sıralaması Araştırması (SEGE-2017)" adlı çalışmada gelişmenin tüm boyutlarını kapsayan 52 göstergeden oluşan seçici veri setinden faydalanılarak oluşturulmuştur. Yakar, Saraçlı ve Yazıcı (2010), Yakar (2013) ile Öz ve Çelebioğlu (2015) tarafindan yürütülen çalışmalarda SEGE değerlerinin iller arasındaki net göçü belirlemede anlamlı sonuçlar verdiği vurgulanmaktadır. $\mathrm{Bu}$ sebeple illerin sosyo-ekonomik gelişmişliğine göre hesaplanan SEGE-2017 endeks değerleri çalışmada çekim merkezlerinin tespitinde tercih edilmiştir. Daha güçlü çekim merkezlerinin tespitinde iller arası mesafe verisinin de kullanılmasının önemine işaret edilmektedir. Bu doğrultuda yapılan literatür taramasında, Bindak (2015) tarafından iller arası mesafe ve nüfus verilerinden 
faydalanılarak Türkiye'de illerin çekim yani cazibe katsayılarının oluşturulduğu görülmüştür.

İllerin cazibe katsayıları, Newton'un evrensel çekim yasasından esinlenerek geliştirilen göç baskısı modelinden faydalanılarak hesaplanmaktadır. Göç olayının yanı sıra ticaret, turizm ve eğitim alanlarındaki hareketliği iyi tahmin performansına sahip olması nedeniyle yaygin olarak kullanılmaktadır (Bindak, 2015, s. 115). Bindak (2015) çalışmasında, Türkiye'de illerin cazibe (çekim) katsayılarını hesaplarken, bu çekim modelinden faydalanarak; il nüfusları ve mesafe verilerini her bir il için 80 adet olmak üzere $81 * 80$ tane $\mathrm{F}$ değeri hesaplayarak, her bir ilin diğer iller üzerindeki cazibe katsayılarını elde etmiştir. Elde edilen cazibe katsayılarının ilin aldığı ve verdiği göçü açıklama düzeyini belirlemek için de istatistiksel olarak tahmin etmeye çalışmış ve analiz neticesinde cazibe katsayılarının ilin aldığı göçün \% 71 'ini, verdiği göçün ise \%64'ünü açıkladığı sonucuna ulaşmıştır.

İncelenen her iki veri setinin de iller arası alınan göçlerini açılama düzeylerinin yüksek ve göçlerle güçlü korelasyona sahip olması sebebi ile çalışmamıza konu olan 47 il içerisindeki göç çekim merkezlerinin tespitinde kullanılmasına karar verilmiştir. Hem sosyo-ekonomik faktörler hem de nüfus büyüklüğü ve komşuluk matrisinin birlikte değerlendirilmesi adına bu iki değişkenin ölçek ortalaması alınarak illerin katsayıları yeniden belirlenmiştir (Tablo 1; Şekil 3).

Veri setlerinin düzenlenmesi ve analiz için uygun hale getirilmesinin ardından SPSS 22 paket programında bağımlı değişken ile bağımsız değişken arasındaki ilişkiyi açıklaması adına regresyon analizi yapılmıştır. Analiz sonucunda; iki değişken arasında güçlü bir korelasyonun olduğu görülmüştür. Bağımsız değişken olarak analize tabi tutulan SEGE ve illerin cazibe katsayıları ortalama değerinin, bağımlı değişken olan illerin göç değerini 0.01 düzeyinde istatiksel olarak anlamlı bir açıklayıcısı olduğu sonucuna ulaşılmıştır (Tablo 2).

Analizde; $\mathrm{y}=2,71 \mathrm{E} 4+5,48 \mathrm{E}-5 * \mathrm{x}$ regresyon modeli sonucuna göre $\mathrm{R}^{2}$ linear $=0,749$ değeri rapor edilmiştir. Bu değer, SEGE ve illerin cazibe katsayıları ortalamasının, illerin aldıkları göç değerlerinin \%74'ü gibi yüksek bir değerle açıkladığını göstermektedir. Kısacası seçilen veri setinin illerin aldıkları göçlerin istatistiksel olarak anlamlı bir açıklayıcısı olduğu görülmüştür. Bu sonuçlar neticesinde, 47 il içerisinde göç çekim merkezlerinin tespitinde SEGE endeks değerleri ve illerin cazibe katsayılarının ortalama değerine göre tespit yapılmasının doğru olacağına karar verilmiştir. Bu iki değişkene dayalı ölçek

Tablo 1: Çalışma Kapsamındaki İllerin SEGE ve Cazibe Katsayıları ile Ortalama Değerleri.

Table 1: The SEDI values, Attraction Coefficients and Average Values of the Provinces Included in The Study.

\begin{tabular}{|c|c|c|c|c|c|c|c|}
\hline iller & $\begin{array}{l}\text { İl Cazibe } \\
\text { Katsayıları }\end{array}$ & $\begin{array}{l}\text { illerin SEGE } \\
\text { değerleri }\end{array}$ & $\begin{array}{l}\text { İllerin Cazibe ve } \\
\text { SEGE ortalamaları }\end{array}$ & iller & $\begin{array}{l}\text { İl Cazibe } \\
\text { Katsayıları }\end{array}$ & $\begin{array}{l}\text { İllerin SEGE } \\
\text { değerleri }\end{array}$ & $\begin{array}{l}\text { İlerin Cazibe ve } \\
\text { SEGE ortalamaları }\end{array}$ \\
\hline Adıyaman & 288023362 & $-0,926$ & 144011681 & Kayseri & 526783420 & 0,561 & 263391710 \\
\hline Ağrı & 91980799 & $-1,752$ & 45990399 & Kırşehir & 133945570 & $-0,085$ & 66972785 \\
\hline Aksaray & 223546371 & 0,271 & 111773186 & Kilis & 100919990 & $-0,571$ & 50459995 \\
\hline Amasya & 142446314 & 0,054 & 71223157 & Konya & 774352717 & 0,668 & 387176359 \\
\hline Ardahan & 17563131 & $-0,983$ & 8781565 & Malatya & 265529771 & $-0,113$ & 132764885 \\
\hline Artvin & 24784723 & $-0,235$ & 12392361 & Mardin & 306987153 & $-1,396$ & 153493576 \\
\hline Batman & 223156683 & $-1,324$ & 111578341 & Muş & 110961271 & $-1,704$ & 55480635 \\
\hline Bayburt & 19780803 & $-0,629$ & 9890401 & Nevşehir & 133945570 & $-0,015$ & 66972785 \\
\hline Bingöl & 91524006 & $-1,208$ & 45762002 & Niğde & 167557865 & $-0,395$ & 83778932 \\
\hline Bitlis & 111399355 & $-1,428$ & 55699677 & Ordu & 326581524 & $-0,486$ & 163290762 \\
\hline Çorum & 245434083 & $-0,262$ & 122717041 & Osmaniye & 406843576 & $-0,367$ & 203421788 \\
\hline Diyarbakır & 639605199 & $-1,074$ & 319802599 & Rize & 86710970 & 0,174 & 43355485 \\
\hline Elazığ & 206041274 & $-0,061$ & 103020637 & Samsun & 345213612 & 0,242 & 172606806 \\
\hline Erzincan & 50246439 & $-0,15$ & 25123219 & Siirt & 107721587 & $-1,405$ & 53860793 \\
\hline Erzurum & 157546999 & $-0,531$ & 78773499 & Sinop & 49239627 & $-0,317$ & 24619813 \\
\hline Gaziantep & $1,052 E+09$ & 0,251 & 526105199 & Sivas & 213948130 & $-0,137$ & 106974065 \\
\hline Giresun & 251445654 & $-0,323$ & 125722827 & Şanlıurfa & 681084031 & $-1,351$ & 340542015 \\
\hline Gümüşhane & 38501889 & $-0,623$ & 19250944 & Şırnak & 92522495 & $-1,788$ & 46261247 \\
\hline Hakkari & 32416031 & $-1,518$ & 16208015 & Tokat & 222841477 & $-0,381$ & 111420738 \\
\hline Hatay & 478101105 & 0,017 & 239050553 & Trabzon & 186017185 & 0,389 & 93008593 \\
\hline Iğdır & 28469281 & $-1,179$ & 14234640 & Tunceli & 21576383 & $-0,439$ & 10788191 \\
\hline Kahramanmaraş & 716254376 & $-0,416$ & 358127188 & Van & 139924605 & $-1,452$ & 69962302 \\
\hline Karaman & 101894222 & 0,177 & 50947111 & Yozgat & 221804619 & $-0,589$ & 110902309 \\
\hline Kars & 45773827 & $-1,125$ & 22886913 & & & & \\
\hline
\end{tabular}

Kaynak: Cazibe katsayıları: Bindak (2014); SEGE değerleri: Sanayi ve Teknoloji Bakanlığı (2019)'dan alınmıştır. 


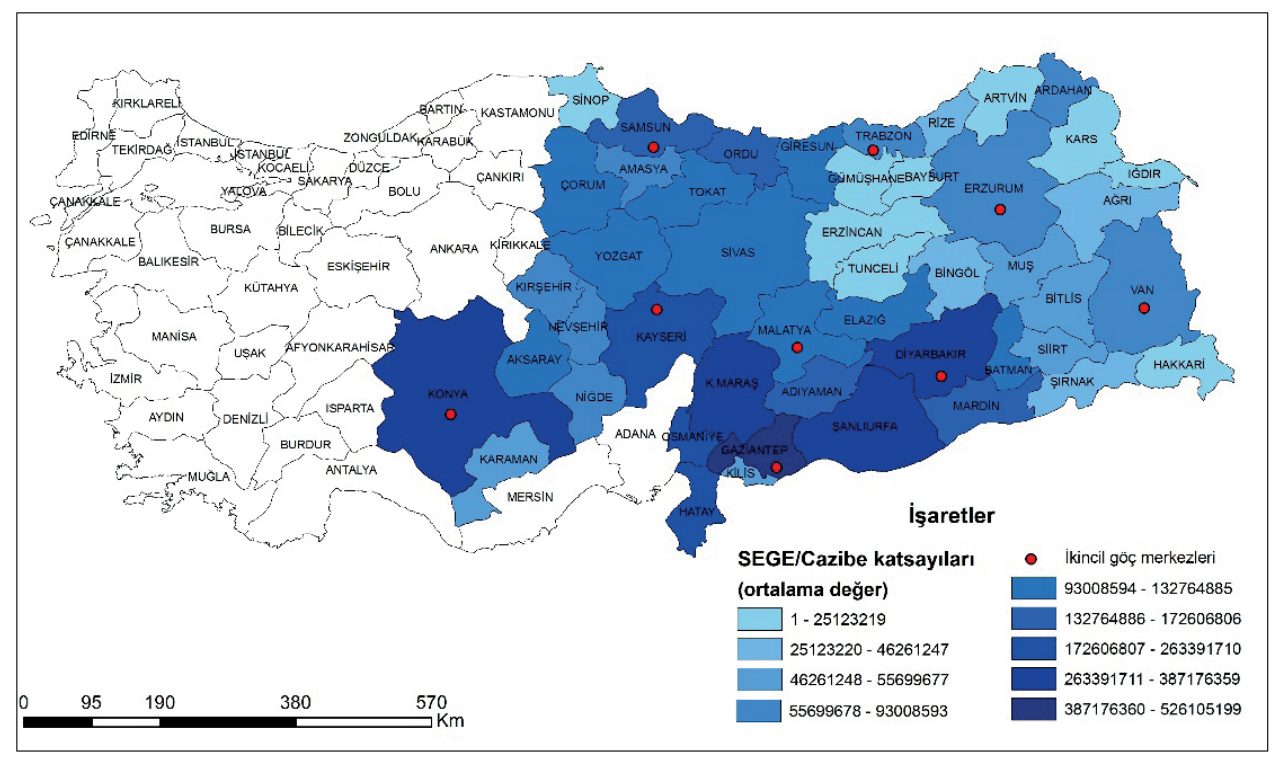

Şekil 3: İkincil Göç Çekim Merkezleri ve Illlerin SEGE/Cazibe Katsayıları.

Figure 3: The Secondary Migration Centers and SEDI/Attraction Coefficients of Provinces.

Tablo 2: Illerin Cazibe ve SEGE Ortalamaları İle Göç Değerlerine Ait Regresyon Analizi Table 2: Regression Analysis of Attraction and SEDI Averages and Migration Values

\begin{tabular}{lllll}
\hline Model & \multicolumn{3}{l}{ Unstandardized Coefficients } & \multicolumn{2}{l}{ Standardized Coefficients } \\
\cline { 2 - 5 } & B & Std. Error & Beta & Sig. \\
\hline (Constant) & 27113,964 & 3262,006 & 8,312 &, 000 \\
SEGE_cazibeort & $5,481 E-5$ &, 000 &, 865 & 4,569 \\
\hline
\end{tabular}

ortalaması yüksek olan illerin çevre illerden aldıkları göç miktarları da göz önünde bulundurularak ikincil göç çekim merkezlerinin tespiti yapılmıştır.

Kastamonu-Antalya hattının doğusunda kalan araştırma sahası içerisinde yer alan iller arasında yer alan Mersin ve Adana illeri zaten uzun zamandan beri birer göç çekim merkezi olduklarından hesaplama dişında tutulmuş, geri kalan 47 il içerisinde yerel olarak komşu il kümeleri arasında göç çekme potansiyeli olan merkezlerin tespiti yapılmaya çalışılmıştır. Değerlendirme neticesinde 47 il içerisinde göç çekim potansiyeline sahip 9 merkezin ön plana çıktığı görülmüştür. Bu ikincil göç çekim potansiyeli olan merkezler; Konya, Kayseri, Gaziantep, Samsun, Malatya, Diyarbakır, Van, Erzurum ve Trabzon şeklinde sıralanmaktadır (Şekil 3). Tespiti yapılan bu merkezlere daha önceki çalışmalarda da değinildiği görülür. Çelik, (2007) tarafından yapılan çalışmada; Gaziantep, Şanlıurfa, Diyarbakır, Erzurum ve Van illerinin bölgesel düzeyde göç çekim potansiyeline sahip merkezler olabileceklerine vurgu yapılmıştır (s. 103). Mutluer (2003) ise 1950'lerden itibaren Adana, Eskişehir ve Samsun gibi illerin bölgesel göç çekiminde önemli merkezler olarak dikkat çektiklerini vurgulamaktadır (s.49). TÜİK göç verilerine göre Gaziantep ve Diyarbakır gibi bölge illeri, Türkiye' de son dönem göç yoğunluğu hesaplamasına göre anlamlı miktarda göç alan merkezler arasında yer almaktadır (Şekil 2). Hatta net göçleri negatif olmasına karşın Adana ve Gaziantep Türkiye'de illerin aldığı göç miktarı bakımdan ilk on sıra içerisinde yer almaktadırlar.

\section{3. İkincil Göç Merkezlerinin Etki Sahalarının Tespiti}

İkincil göç çekim merkezleri olarak ön plana çıkan bu 9 ilin etki sahalarının tespiti için de TÜİK göç verilerinden faydalanılmıştır. $\mathrm{Bu}$ merkezlerin, yakın çevresindeki illerle olan göç alış/verişleri irdelendiğinde; sınır komşuluğu olan illerden ikincil merkez olarak anlamlı miktarlarda göç aldıkları ve bir bütünleşme sağladıkları görülmüştür. Şekilde "paylaşılan iller" olarak ifade edilenler ise bir çekim merkezi ile anlamlı bütünleşme göstermeyip, yakın konumdaki birden fazla göç merkezini ikincil göç merkezi olarak kullanmaktadırlar. Bu iller; Siirt, Hatay, Kahramanmaraş, Şırnak, Giresun, Kırşehir, Muş, Bingöl, Bayburt, Iğdır, Artvin, Tunceli ve Ardahan illerinden oluşmaktadır (Şekil 4). 


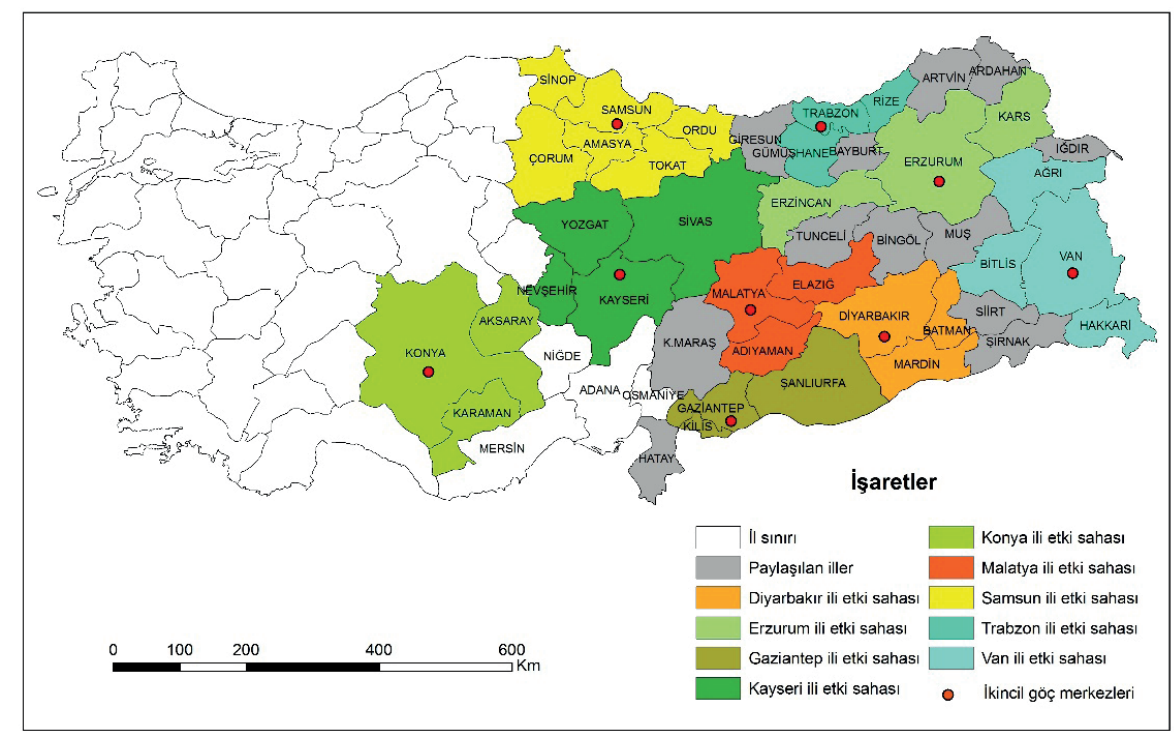

Şekil 4: İkincil Göç Çekim Merkezleri ve Etki Sahaları.

Figure 4: The Secondary Migration Attraction Centers and Their Impact Area.

TÜIK göç verilerine göre hesaplanan ikincil göç çekim merkezlerinin etki sahaları ise Şekil 4 'teki gibi belirmektedir. Bu merkezlerden Samsun'un ilinin etki sahasinda; Sinop, Ordu, Tokat, Amasya ve Çorum illerinin yer aldığ görülür. $\mathrm{Bu}$ il grubundan meydana gelen göçlerin önemli bir kısmı İstanbul, Ankara ve İzmir gibi ulusal göç merkezlerine doğru olmaktadır. $\mathrm{Bu}$ merkezlerden sonra ise en fazla göç Samsun iline gerçekleştiğinden, ikincil hedef merkez olarak ön plana çıkmaktadır (Tablo 3).
Bir diğer göç çekim merkezi olarak beliren Van ilinin etki sahasında ise sınır komşuluğu yaptığı; Ağrı, Bitlis ve Hakkâri illeri yer almaktadır. Bu illerden; Ağrı ve Bitlis'in, Van ilini ikincil göç merkezi, Hakkâri'nin ise Van'ı birincil göç merkezi olarak kullandığı görülür (Tablo 4). Hakkâri örneğinde olduğu üzere araştırmaya konu olan bazı iller, etki sahasında kaldığı merkez ili birinci derece göç merkezi olarak kullanmaktadır. Bu illerden Elazığ en fazla göçü Malatya'ya, Osmaniye ise Adana'ya, Kilis ve Şanlıurfa ise Gaziantep'e göndermektedir. Benzer şekilde, Nevşehir ili Kayseri'yi, Karaman ise Konya'yı birincil göç merkezi olarak kullanmaktadır.

Tablo 3: Samsun'un Etki Sahasındaki Illerin En Fazla Göç Verdiği Merkezler.

Table 3: The Centers Which the Provinces in the Impact Area of Samsun Highest Send Migration.

\begin{tabular}{|c|c|c|c|c|c|c|c|c|c|}
\hline Amasya & Verdiği Göç & Ordu & Verdiği Göç & Tokat & Verdiği Göç & Çorum & Verdiği Göç & Sinop & Verdiği Göç \\
\hline İstanbul & 3176 & İstanbul & 22685 & İstanbul & 18367 & Ankara & 8115 & İstanbul & 7615 \\
\hline Ankara & 1562 & Samsun & 4395 & Ankara & 2682 & İstanbul & 3059 & Samsun & 1159 \\
\hline Samsun & 1535 & Ankara & 2826 & Kocaeli & 1895 & Samsun & 1123 & Kocaeli & 888 \\
\hline Tokat & 1007 & Giresun & 1430 & Tekirdağ & 1554 & İzmir & 796 & Tekirdağ & 714 \\
\hline Çorum & 797 & Kocaeli & 1353 & Samsun & 1294 & Amasya & 742 & Ankara & 697 \\
\hline
\end{tabular}

Kaynak: TÜiK iller arası göç verilerinden hazırlanmıştır.

Tablo 4: Van'ın Etki Sahasındaki Illerin En Fazla Göç Verdiği Merkezler.

Table 4: The Centers Which the Provinces in the Impact Area of Van Highest Send Migration.

\begin{tabular}{|c|c|c|c|c|c|}
\hline Ağrı & Verdiği Göç & Bitlis & Verdiği Göç & Hakkâri & Verdiği Göç \\
\hline İstanbul & 6481 & İstanbul & 4870 & Van & 3113 \\
\hline İzmir & 2006 & Ankara & 1829 & İstanbul & 1823 \\
\hline Ankara & 1923 & Van & 956 & Ankara & 1158 \\
\hline Van & 1313 & Bursa & 831 & İzmir & 454 \\
\hline Bursa & 1288 & İzmir & 713 & Mersin & 450 \\
\hline
\end{tabular}

Kaynak: TÜIK iller arası göç verilerinden hazırlanmıştır. 
Tablo 5: Kayseri'nin Etki Sahasındaki IIllerin En Fazla Göç Verdiği Merkezler.

Table 5: The Centers Which the Provinces in the Impact Area of Kayseri Highest Send Migration.

\begin{tabular}{llllllll}
\hline Nevşehir & Verdiği Göç & Yozgat & Verdiği Göç & Kahramanmaraş & Verdiği Göç & Sivas & Verdiği Göç \\
\hline Kayseri & 1918 & Ankara & 7525 & İstanbul & 4151 & İstanbul & 12015 \\
İstanbul & 1682 & Kayseri & 3186 & Kayseri & 3622 & Kayseri \\
Ankara & 1278 & İstanbul & 2684 & Gaziantep & 3000 & Ankara & 3964 \\
Kırşehir & 578 & Bursa & 854 & Ankara & 2480 & İmir \\
Konya & 407 & Kırşehir & 640 & Osmaniye & 2007 & Tokat & 1409 \\
\hline
\end{tabular}

Kaynak: TÜIK iller arası göç verilerinden hazırlanmıştır.

Bir diğer ikincil göç merkezi olan Kayseri ise, etki sahasında yer alan; Nevşehir'den birincil, Yozgat, Kahramanmaraş ve Sivas illerinden de ikincil göç merkezi olarak nüfus çekmektedir (Tablo 5). Rize ve Gümüşhane Trabzon'u, Erzincan ve Kars Erzurum'u, Aksaray Konya'yı, Adıyaman ise Malatya'yı ikincil göç merkezi olarak kullanmaktadır (Şekil 4). Batman ve Mardin illeri de İstanbul, Ankara, İzmir gibi ulusal göç merkezlerinden sonra en fazla göçü Diyarbakır iline göndermektedirler.

Yerel düzeyde etkiye sahip ikincil göç çekim merkezlerinin etki sahaları yani anlamlı miktarlarda göç aldıkları iller bu şekilde iken, araştırma sahamızda yer alan Mersin ve Adana illeri ise göç etki sahaları bakımından farklılık göstermektedir. Bu iki il sadece komşu il kümelerinden değil, farklı bölgelerden de göç çekebilmektedirler. Bu doğrultuda bölge illeri için önemli göç hedef merkezi durumundadırlar. Ülkemizin eski göç çekim merkezlerinden olan Adana'nın geçmişe nazaran çevreden aldığ göç yoğunluğu azalmış, hatta göçlerle hızlı nüfus artış1 yaşanan ilin göç yoğunluğunu Mersin ve Antalya gibi illere kaydırdığı görülür. Adana ili her ne kadar göç yoğunluğunu bu iki ile kaptırmış olsa da, son dönem TÜiK göç verilerine göre halen bölge illeri için önemli bir göç hedefi olduğu görülür. Günümüzde il, yakın konumdaki; Osmaniye ve Niğde illeri yanı sıra başta Şanlıurfa olmak üzere Güneydoğu Anadolu bölge illerinden halen önemli miktarda göç almaktadır.

Mersin ili ise, yakın dönemlerde yakaladığı gelişim sayesinde Adana'nın göç yoğunluğunu da kendine çekerek bölgesel göç çekim merkezi haline gelmiştir. Bu sebeple Mersin, artık sadece yakın çevreden değil, daha uzak illerden de göç çekebilmektedir. Mersin ilinin göç etki sahası; Güneydoğu (Şanlıurfa, Siirt, Şırnak, Adıyaman, Mardin), Doğu Anadolu (Bitlis, Hakkâri, Muş) ve İç Anadolu bölge illerine (Sivas, Niğde) kadar genişlemektedir. İl yakalamış olduğu gelişim sayesinde; Adana, Diyarbakır, Van, Malatya ve Gaziantep gibi merkez illerden de net göç almaktadır.

\section{4. İkincil Göç Merkezlerinin Aldığı Göçler Üzerinde Etkili Olan Faktörler}

Türkiye'de iller arasında meydana gelen göçlerin nedenleri irdelendiğinde; iş ve istihdam gibi ekonomik beklentiler önemli bir göç nedeni olmakla birlikte, tek göç nedeni olmadığı görülür. Çünkü göç etme nedenlerine bakıldığında; iş arama, işini geliştirme, iş değişikliği gibi ekonomik nedenlerin yanı sıra, eğitim, evlilik/boşanma ve sağlık gibi faktörlerinde etkili olduğu görülür. Ancak göçe karar verme nedenleri içerisinde en önemlisini ise "hanedeki fertlerden birine bağımlı göç" nedeni oluşturmaktadır (Tablo 6). Göçmen İlişkiler Ağı (Network) Kuramı; aile fertleri, kişinin etrafındakiler ve diğer yakın ilişkilere dayalı oluşan ağın göç olgusunun hızlanmasında etkili olduğunu vurgular. Bu hususta Gurak ve Caces, (1992) akrabalık, arkadaşlık ve topluluk bağlarına dayanan ağların göç gönderen ve alan toplulukları birbirine bağladığı ve göçmenlerin nüfusu için tutarlı bir yapı sağladığını ifade etmektedir (s. 150). Turut ve Özgür, (2018) ise göçmen ağlarının göç ve göç sonrası uyum süreçlerinin çeşitli aşamalarında, çok önemli bir sosyo-mekânsal sermaye işlevi yerine getirerek göçlerin devamlılığına etkide bulunduğuna vurgu yapmaktadırlar (s. 176). Bu nedenle, göçmen ağlarını analiz ederken; göçmenlerin hedef toplumda ağ oluşumuna nasıl katıldığı, farklı insanlarla sosyal bağların nasıl kurulduğunu da dikkate almak gerekir (Ryan, 2011, s. 709).

Tablo 6: Türkiye'de Göç Etme Nedenine Göre Göç Eden Nüfus Oranı. Table 6: The Migrating Population Ratio in Turkey According to the Reasons for Migrating.

\begin{tabular}{lc}
\hline Göç Etme Nedeni & Göç Eden Nüfus Oranı (\%) \\
\hline Iş aramak/Bulmak & 12,2 \\
Tayin/İş değişikliği & 13,4 \\
Eğitim & 22,6 \\
Evlilik/Boşanma & 7,5 \\
Sağlık & 1,0 \\
Hanedeki fertlerden birine bağımlı göç & 41,5 \\
Diğer & 1,8 \\
Toplam & 100,0 \\
\hline
\end{tabular}

Kaynak: TÜiK, Nüfus ve Konut Araştırması, 2011. 
Araştırmamıza konu olan iller arasındaki göç olgusu da irdelendiğinde; ulaşım, yakınlık, iş, sağlık ve eğitim gibi nedenlere ilaveten geçmişte kurulan sosyal ve ekonomik ağların yani ilişkilerin göçlerin yönünde önemli etkisi olduğu anlaşılır. Örneğin, Osmaniye, Kilis ve Karaman illerinde olduğu üzere bir dönem ilçesi olduğu illere fazla göç vermesi bu ağlarla alakalıdır. Yine geçmişte üst kademe olarak (eğitim, sağlı ve ticaret) kullanılan illere günümüzde ikincil derece de yoğun göçlerin olması geçmişte kurulan ticari ve sosyal ağlarla alakalıdır. Bu iller arasındaki fiziki yakınlık ve kültürel benzerlik de beraberinde sosyal ve ekonomik yakınlığı geliştirmiştir.

Araştırmamıza konu olan bazı illerde ise daha farklı bir ilişki ağı oluştuğu görülür. Net bir ikincil göç merkezi olmayan bu illerin yakın iki merkezi göç gönderiminde ortak olarak kullandığı görülmektedir (Şekil 4). Giresun ili, Trabzon ili ile komşu olmasına karşın Ordu ve Samsun illerine de hemen hemen aynı miktarlarda göç vermektedir. Bayburt ve Artvin; Erzurum ve Trabzon'u, Kahramanmaraş; Kayseri ve Gaziantep'i, Hatay; Adana ve Gaziantep'i ikincil göç merkezi olarak kullanmaktadır. Bu durum benzer sosyal ve ekonomik ağların birden fazla yakın merkezle oluşturulduğunu göstermektedir. Nitekim 1982 yılında DPT tarafından hazırlanan "Türkiye'de Yerleşme Merkezlerinin Kademelenmesi" adlı çalışmada da; belirlenen üst kademe merkezlerin belli illeri doğrudan, bazı illeri ise başka bir üst kademe merkez ile paylaşarak etkilediği belirtilmektedir. Örneğin bugün ikincil göç merkezi olarak hem Samsun hem de Trabzon'u kullanan Giresun ili 1982'de hazırlanan bu çalışmada da iki ilin paylaşarak etkilediği alan olarak ifade edilmektedir. Yine aynı çalışmada benzer şekilde Kahramanmaraş ilinin Kayseri, Adana ve Gaziantep illeri tarafından paylaşılarak etkilendiği vurgulanmaktadır (DPT, 1982). Bu durum geçmişten kurulan ilişkilerin günümüzde de etkisinin devam ettiğinin göstergesidir. Geçmişte kurulan bu ağlara bağlı olarak da geçmişten günümüze meydana gelen göçler bu merkezlere doğru devam etmektedir. İkincil merkezlerin çevre illerden göç almasında etkili olan geçmişte kurulan bu ağların yanı sıra etkisi olacağı düşünülen; yakınlık $(\mathrm{km})$, nüfus büyüklüğü, illerde yaşam endeksi değerleri ve sosyo-ekonomik değişkenlere dayalı analizler de yapılmıştır.

İllerin aldığı göçler üzerinde anlamlı etkiye sahip olduğu yapılan çalışmalarla vurgulanan "illerde yaşam endeksi" değerleri; konut, çalışma hayatı, gelir ve servet, sağlık, eğitim, çevre, güvenlik, sivil katılım, altyapı hizmetlerine erişim, sosyal yaşam ve yaşam memnuniyeti olmak üzere toplam 11 değişkenden oluşmaktadır. TÜiK tarafından hazırlanan bu veri seti ikincil göç çekim merkezlerinin aldığ 1 göçler üzerindeki etkisi açısından stepwise metodu ile doğrusal regresyon modeliyle tahmin edilmeye çalışılmıştır. İllerdeki yaşam endeksini yansitan bu 11 faktörden, "güvenlik" ve "sosyal yaşam" endekslerinin alınan göçler üzerinde anlamlı ilişkisi olduğuna dair bir modele ulaşılmıştır (Tablo 7). Göçlerle anlamlı ilişkisi bulunan bu iki değişkenden güvenlik değiş̧keninin alınan göçleri negatif yönde etkilemekte olduğu görülür. Beklendiği üzere Doğu ve Güneydoğu Anadolu bölge illerinde güvenlik kaygısından kaynaklı göçlerin gerçekleşmediği, aksine bu illerdeki güvenlik kaygısından ötürü göçlerin olumsuz etkilendiği anlaşılmaktadır. Bu durumu, Kandemir (2017) göç alan illerde aşırı nüfusa bağlı olarak ortaya çıkan güvenlik sorunlarına bağlanmaktadır (s. 280). İllerde yaşam endeksi değerleri içerisinde, ikincil göç merkezlerinin aldığ gö̈çler üzerinde pozitif ve güçlü yönde ilişkiye sahip tek değişken ise "sosyal yaşam" değişkenidir. Bu değişken; illerin sinema, tiyatro ve alışveriş merkezleri gibi imkânları ile sosyal hayat memnuniyeti göstergelerinden elde edilen ortalama bir değerdir.

Yakar (2013), tarafından yapılan çalışmada Türkiye'de iller arası net göçlerin \%64'ünü illerin sosyo-ekonomik gelişmişlik düzeyinin belirlediği sonucuna ulaşılmıştır. Kandemir (2017) tarafindan "illerde yaşam endeksi" veri seti üzerinden yapılan çalışmada ise, Türkiye'de net göç alan illerin aldığı göçlerle; gelir ve servet ile altyapı hizmetlerine erişimden oluşan faktörler arasında anlamlı ve pozitif yönde bir ilişkinin olduğu sonucuna ulaşılmıştır (s. 282). Ancak, ikincil göç merkezlerinin aldıkları göçler üzerine SPSS ortamında yapılan regresyon analizi sonuçlarına göre alınan göçlerde SEGE değerlerinin \%25 gibi

Tablo 7: Illerde Yaşam Endeksi Değerleri İle Göçler Arasındaki Illişkinin Regresyon Analizi.

Table 7: Linear Regression Analysis on the Relationship Between the Life Index in Provinces and Migrations.

\begin{tabular}{|c|c|c|c|c|c|c|}
\hline \multirow{2}{*}{ Model } & \multicolumn{2}{|c|}{ Unstandardized Coefficients } & \multirow{2}{*}{$\begin{array}{c}\text { Standardized Coefficients } \\
\text { Beta }\end{array}$} & \multirow{2}{*}{$\mathbf{t}$} & \multirow{2}{*}{ Sig. } & \multirow{2}{*}{ Adjusted R Square } \\
\hline & B & Std. Error & & & & \\
\hline (Constant) & 81632,803 & 12091,046 & & 6,752 &, 000 & \\
\hline Güvenlik & $-133056,474$ & 27873,245 & $-1,150$ & $-4,774$ & ,001 & ,387 \\
\hline Sosyal yaşam & 82763,972 & 27565,329 & ,723 & 3,002 & 017 &, 676 \\
\hline
\end{tabular}

Dependent Variable: Alınan göç değerleri

Predictors: (Constant), Güvenlik, Sosyal yaşam 
düşük düzeyde etkisi olduğu görülmüştür. İllerin cazibe katsayıları değişkeni ise alınan mevcut göçlerin \%71'ini açıklamaktadır. Bu netice ikincil göç merkezlerinin aldığı göçlerin sosyo-ekonomik gelişmişlikten daha çok kentleşmeye ve km cinsinden yakınlığa bağlı nedenlerden kaynaklı olduğunu gösterir. İller arası yakınlık ise eğitim, sağlık, ticari ve sosyal ağların kurulmasında avantaj oluşturarak göçlerin devamlılığına katkı sunmaktadır.

Peki, bu merkezlerin göç alma potansiyellerinin artırılmasına katkı sağlanması adına merkezlerin hangi yönlerinin geliştirilmesi gerekir? Bu sorunun cevabı için de göçlerle istatistiksel olarak anlamlı, güçlü ve pozitif yönlü ilişkiye sahip değişkenlerin belirlenmesine çalışılmıştır. İkincil göç çekim merkezi olan illerin göç almasıyla ilişkisi olduğu düşünülen; nüfus, eğitim, sağlık, kentleşme, ulaşım, asayiş ve ekonomik faktörlerden oluşan toplam 16 değişken üzerinden bir analiz daha yapılmıştır. Değişkenler belirlenirken, daha önceki çalışmalarda iç göçlerde etkisi ölçülen sosyo-ekonomik parametrelere uygun olmasına dikkat edilmiştir. Bu doğrultuda TÜİK’ten elde edilen amaca uygun verilerden faydalanılmıştır. Oluşturulan bu değişkenler ile illerin aldığ1 göç değişkeni arasındaki ilişki korelasyon analizi ile sorgulanmıştır. Yapılan analiz sonucuna göre; değişkenler arasından; alınan göç ile 0.05 ve 0.01 düzeyinde istatistiksel olarak anlamlı ilişkiye sahip 8 değişken olduğu görülmüştür. İkincil göç merkezlerinin aldıkları göçler ile ilişkili olan bu değişkenler; istihdam, sanayi, öğretmen sayısı, hastane imkânları, nüfus ve kentleşme düzeyinden oluşmaktadır (Tablo 8).

Bu değişkenlerin korelasyon katsayıları değer aralığına göre ilişki düzeyleri incelendiğinde; alınan göçler ile anlamlı ve pozitif yönde kuvvetli ilişkiye sahip oldukları görülür. Dolayısıyla istatistiksel olarak anlamlı ilişkiye sahip olan bu değişkenlerin desteklenmesi ve geliştirilmesi, merkez illerin sosyo-ekonomik gelişmişliğini artırarak yakın konumdaki illerden gerçekleşen göçlerden daha fazla pay almasını sağlayacaktır.

\section{SONUC VE ÖNERILER}

Türkiye'de iller arası göçlerde, göçlerin başladığı dönemden günümüze kadar göç yönü ve hedef iller genel olarak değişmemiş, süreç içerisinde bu göç alan illerin yakınında yeni çekim merkezleri oluşmuştur. Ancak geri kalan bölge ve bölümlerde ise bu tarz bölgesel çekim merkezleri gelişememiştir. Bu durum doğal nüfus artışına ilaveten alınan göçlerle daha da kalabalıklaşan ulusal ölçekteki göç çekim merkezlerinde; çevre, altyap1, istihdam, trafik ve toplumsal birçok sorunu ortaya çıkarmaktadır. Buna karşın göç veren bölge ve iller ise nüfusun azalmasına bağlı olarak hem yatırımları ve hem de nitelikli işgücünü kaybetmektedirler. Bu da illerin sosyo-ekonomik geri kalmışlığını daha fazla artırmaktadır. Tandoğan (1998)'inde ifade ettiği üzere, göçleri durdurmak mümkün olmadığına göre, göçlerin kontrol altına alınması ve yönetilmesi adına politikaların geliştirilmesi zorunluluktur. Bu doğrultuda atılacak adımlardan birisi; kalkınma planlarında da vurgulandığı üzere göçü bölge içerisinde tutabilecek bölgesel veya daha alt düzeyde göç çekim merkezlerinin tespiti olmalıdır.

Literatürde bir ilin göçler için cazip olmasında, sosyoekonomik gelişmişlik ve göç mesafesinin önemine vurgu yapılmaktadır. Araştırmamıza konu olan 47 il arasında göç çekim merkezi olma potansiyeline sahip merkezlerin tespiti için literatürde vurgulanan bu kuramsal bakış açısına uygun değerlendirmeler yapılmıştır. Değerlendirmeler neticesinde; 9 ilin ikincil göç çekim merkezi olarak ön plana çıktığ görülmüştür. Bu merkezler; Konya, Kayseri, Gaziantep, Samsun, Malatya, Diyarbakir, Van, Erzurum ve Trabzon şeklinde sıralanmaktadır.

Tablo 8: Seçili Değişkenler İle Alınan Göçler Arasındaki Illişkinin Korelasyon Analizi Sonuçları. Table 8: The Results of Correlation Analysis on the Relationship Between Selected Variables and Received Migrations

\begin{tabular}{|c|c|c|c|c|c|}
\hline \multicolumn{3}{|c|}{ Correlations } & \multicolumn{3}{|c|}{ Correlations } \\
\hline & & Alınan göç & & & Alınan göç \\
\hline \multirow[t]{2}{*}{ Toplam nüfus } & Correlation Coefficient & $806^{* *}$ & Sinema ve tiyatro sayısı & Correlation Coefficient &, $794^{* *}$ \\
\hline & Sig. (2-tailed) &, 005 & & Sig. (2-tailed) &, 006 \\
\hline \multirow[t]{2}{*}{ İstihdam } & Correlation Coefficient & $964^{* *}$ & Kentsel nüfus oranı & Correlation Coefficient &, $758^{*}$ \\
\hline & Sig. (2-tailed) & ,000 & & Sig. (2-tailed) & 011 \\
\hline \multirow[t]{2}{*}{ GSMH } & Correlation Coefficient & $855^{* *}$ & Sanayi (GSYH) & Correlation Coefficient &, $782^{* *}$ \\
\hline & Sig. (2-tailed) & ,002 & & Sig. (2-tailed) & ,008 \\
\hline \multirow[t]{2}{*}{ Orta öğretim öğretmen sayısı } & Correlation Coefficient &, $806^{* *}$ & Hastane yatak sayısı & Correlation Coefficient &, $636^{*}$ \\
\hline & Sig. (2-tailed) & ,005 & & Sig. (2-tailed) & 048 \\
\hline
\end{tabular}

\footnotetext{
**. Correlation is significant at the 0.01 level (2-tailed).
}

*. Correlation is significant at the 0.05 level (2-tailed). 
Merkezlerin aldıkları göçler üzerinde etkisi olan faktörlerin tespiti de yapılmıştır. Yapılan analizlere göre; alınan göçler üzerinde sosyo-ekonomik gelişmişliğin etkisinin oldukça düşük düzeyde kaldığı görülmektedir. Sosyo-ekonomik gelişmişliği temsilen kullanılan SEGE endeks değerleri alınan göçlerin $\% 25$ 'ini açıklarken, nüfus ve mesafe verilerinden hesaplanan "illerin cazibe katsayıları" verisi ise göçlerin \%71'ini açılamaktadır. TÜİK'ten elde edilen "illerin yaşam endeksi" değerlerine dayalı analiz neticesinde ise illerin; sinema, tiyatro ve alışveriş merkezleri gibi kentsel imkânları ile sosyal hayat memnuniyeti göstergelerinin ortalama değeri olan "sosyal yaşam" endeksinin alınan göçlerle anlamlı ve pozitif yönde ilişkisi olduğu sonucuna ulaşılmıştır. Dolayısıyla ikincil göç merkezlerinin mevcutta aldıkları göçlerde ekonomik faktörlerin etkisinin düşük düzeyde kaldığı, kentleşme ve iller arası mesafe değerlerinin göçlerde daha etkili olduğu anlaşılmaktadır.

Ayrıca "istihdam, sanayileşme, öğretmen sayısı, hastane imkânları ve nüfus" gibi şehirsel fonksiyonların geliştirilmesi ve şehirlere yeni fonksiyonların kazandırılması bu merkezlerin göçler için cazibe merkezi olma potansiyelini artıracaktır. Çünkü daha önceki çalışmalarda iç göçlerde etkisi ölçülen 16 sosyoekonomik parametreye dayalı olarak yapılan korelasyon analizi sonucuna göre bu sekiz değişkenin ikincil göç merkezlerine olan göçlerle 0.05 ve 0.01 düzeyinde istatistiksel olarak anlamlı ve pozitif yönde kuvvetli ilişkiye sahip oldukları sonucuna ulaşılmıştır.

Sonuç olarak, bu illerin belirtilen güçlü yönlerinin geliştirilmesi, çevreden kaynaklanan göçlerden daha fazla pay almalarını sağlayacaktır. Türkiye'de iller arası göçleri ele alan çalışmalarda da vurgulanan ortak nokta, sosyo-ekonomik geri kalmışlık ile verilen göçler arasında doğru orantı olduğu, dolayısıyla illerin gelişme düzeyi arttıkça göç veren illerden kaynaklanan nüfus hareketlerinin de azalacağı hususudur. Burada bahsi geçen gelişme düzeyi sadece ekonomik yönden gelişmenin sağlanması anlamında olmayıp, gelişmenin tüm yönlerini kapsayan çok boyutlu toplumsal gelişmeyi kastetmektedir. İkincil göç merkezlerinde sağlanan bu gelişmenin yanı sıra merkezlerin etki sahasında bulunan illerle olan sosyal ve kültürel birliktelik ve düşük maliyetli mesafe etkenleri ile daha da güçlü göç çekim merkezi olmalarını sağlayacaktır. Böyle bir durumda, göçlerin bölge içerisinde kalması nüfusun ve yatırımların yurt geneline daha dengeli yayılmasına katk1 sağlayacaktır. Aynı zamanda sürekli göç alan illerdeki göç baskısının düşmesine ve göçlere bağlı ortaya çıkan sorunların da azalmasına katkı sağlayacaktır.
Hakem Değerlendirmesi: Dış bağımsız.

Çıkar Çatışması: Yazarlar çıkar çatışması bildirmemiştir.

Finansal Destek: Yazarlar bu çalışma için finansal destek almadığını beyan etmiştir.

Peer-review: Externally peer-reviewed.

Conflict of Interest: The authors have no conflict of interest to declare.

Grant Support: The authors declared that this study has received no financial support

\section{KAYNAKÇA/REFERENCES}

Abar, H. (2011). Türkiye'de iller arası göçün belirleyicileri: Mekânsal ekonometrik model yaklaşımı. (YL Tezi) Atatürk Üniversitesi Sosyal Bilimler Enstitüsü, Erzurum.

Albayrak, N. ve Abdioğlu, Z. (2017). Türkiye'de iç göçü etkileyen faktörlerin analizi, Researcher: Social Science Studies, 5(10), 293-309.

Arınç, K. (2016). Doğal Beşeri, İktisadi ve Siyasi Yönleriyle Doğu ve Güneydoğu Anadolu Bölgeleri. Erzurum: Eser Ofset.

Aydoğdu, M. ve Bakırc1, M. (2020). Şehirden kırsal alanlara ziyarette köyün çekici faktörlerinin analizi: Bağlıca köyü örneği (Sinop/ Boyabat), Coğrafya Dergisi, 40, 13-24 .

Bindak, R. (2015). İller arası göç tahmini için bir çekim (cazibe) modeli önerisi. Sosyal Bilimler Araştırma Dergisi, 4(2), 111-120.

Bostan, H. (2017). Türkiye'de iç göçlerin toplumsal yapıda neden olduğu değişimler, meydana getirdiği sorunlar ve çözüm önerileri. Coğrafya Dergisi, 35, 1-16.

Bülbül, S. ve Köse, A. (2010). Türkiye'de bölgelerarası iç göç hareketlerinin çok boyutlu ölçekleme yöntemi ile incelenmesi. Ístanbul Üniversitesi İşletme Fakültesi Dergisi, 39(1), 75-94.

Castles, S. and Miller, M. J. (1998). The age of migration: international population movements in the modern world, (second edition), London: Macmillan Press.

Çağlayan, S. (2006). Göç kuramlari, göç ve göçmen ilişkisi. Muğla Üniversitesi Sosyal Bilimler Enstitüsü Dergisi, 17, 67-91.

Çağlayan, S. (2013). Göç kavramı ve kuramları, F. Güneş (Ed.) Kent sosyolojisi içinde (s.84-115), Eskişehir: Anadolu Üniversitesi Web-Ofset.

Çelik, F. (2006). İç göçlerin itici ve çekici güçler yaklaşımı ile analizi. Erciyes Üniversitesi İktisadi ve İdari Bilimler Fakültesi Dergisi, 27, 149-170.

Çelik, F. (2007). Türkiye'de iç göçler: 1980-2000. Erciyes Üniversitesi Sosyal Bilimler Enstitüsü Dergisi, 22(1), 87-109.

DPT (1989). 6. Beş Yıllık Kalkınma Planı (1990-1994), Yayın no: DPT:2174, Ankara. https://www.sbb.gov.tr/kalkinma-planlari/

DPT (2000). 8. Beş Yıllık Kalkınma Planı, Bölgesel Gelişme Özel İhtisas Komisyonu Raporu, DPT:2502-ÖIK:523,Ankara. https://www.sbb. gov.tr/wp-content/uploads/2018/11/08_BolgeselGelisme.pdf

DPT (1982). Türkiye'de Yerleşme merkezlerinin kademelenmesi -ülke yerleşme merkezleri sistemi- Cilt-I, Başbakanlık Devlet Planlama Teşkilatı, Kalkınmada Öncelikli Yöreler Başkanlığı, DPT:1806, Ankara.

Dücan, E. (2016). Türkiye'de iç göçün sosyo-ekonomik nedenlerinin bölgesel analizi. Ekonomik ve Sosyal Araştırmalar Dergisi, 12(2), 167-183. 
Ela Özcan, E. D. (2017). Çă̆daş göç teorileri üzerine bir değerlendirme. İs ve Hayat, 2(4), 183-215.

Erdoğan, T. (2019). Kavramsal ve kuramsal açıdan göç olgusu, A. Akgöz, D. Yörük ve H. Karpuz (Ed.) Konya Ticaret Odası Konya kitabı XVII geçmişten günümüze göçler içinde (s.17-43), Konya: Anadolu Ofset.

Ghatak, S., Levine, P., and Price, S. W. (1996). Migration theories and evidence: an assessment. Journal of Economic Surveys, 10(2), 159198. https://doi.org/10.1111/j.1467-6419.1996.tb00008.x

Görgün, M. (2017). Küreselleşme sürecinde göçmen ilişkileri ağının önemi. Süleyman Demirel Üniversitesi İktisadi ve İdari Bilimler Fakültesi Dergisi, 22(Göç Özel Sayıs1), 1317-1327.

Gurak, D. T. and Caces, M. F. (1992). Migration networks and the shaping of migration systems, In Kritz, M.M., L.L. Lim and H. Zlotnik (Eds.) International Migration Systems: A Global Approach (pp. 150-176). Oxford: Clarendon Press.

Güllüpınar, F. (2012). Göç olgusunun ekonomi-politiği ve uluslararası göç kuramları üzerine bir değerlendirme. Yalova Sosyal Bilimler Dergisi, 2(4), 53-85.

Gürbüz, M. ve Karabulut, M. (2007). Türkiye'de iller arası göçler ile sosyo-ekonomik özellikler arasındaki ilişkilerin analizi, 38. ICANAS (10-15 Eylül 2007), Çevre, kentleşme sorunları ve çözümleri içinde (s. 455-469), Ankara. Türkiye.

İçduygu, A. ve Sirkeci, İ. (1999). Cumhuriyet dönemi Türkiye'sinde göç hareketleri. O. Baydar, (Ed.), 75 Yllda Köylerden Şehirlere içinde (s. 249-268), İstanbul: Tarih Vakfi Yayınları.

Işık, Ş. (2005). Türkiye'de kentleşme ve kentleşme modelleri. Ege Coğrafya Dergisi, 14, 57-71.

Kalkınma Bakanlığı, (2013). 10. Kalkınma Planı (2014-2018), Ankara. https://www.sbb.gov.tr/kalkinma-planlari/

Kandemir, O. (2017). Refah göstergeleri bağlamında Türkiye'de iller arası iç göç hareketlerinin analizi, Insani ve Toplum Bilimleri Araştırmaları Dergisi, 6(1), 275-288.

Kocaman, T. (2008). Türkiye'de iç göçler ve göç edenlerin nitelikleri (1965-2000). TC Başbakanlık, Devlet Planlama Teşkilatı, Sosyal Sektörler ve Koordinasyon Genel Müdürlüğü, Ankara.

Koday, S., Koday, Z., ve Akbaş, F. (2018). Gördes büyükşehir ilçesinde nüfus hareketleri, Atatürk Üniversitesi Sosyal Bilimler Enstitüsü Dergisi, 22(Özel Sayl), 523-556.

Kundu, A. and Gupta, S. (1996). Migration, urbanisation and regional inequality. Economic and Political Weekly, 31(52), 3391-3398. https://www.jstor.org/stable/4404940

Lee, E. S. (1966). A theory of migration. Demography, 3(1), 47-57. https://www.springer.com/journal/

Massey, D. S., Arango, J., Hugo, G., Kouaouci, A., Pellegrino, A., \& Taylor, J. E. (1993). Theories of international migration: A review and appraisal. Population and development review, 19(3), 431-466. https://www.jstor.org/stable/2938462

Mutluer, M. (2003). Uluslararası göçler ve Türkiye: Kuramsal ve ampirik bir alan aAraştırması-Denizli, İstanbul: Çantay.

Öz, İ. ve Çelebioğlu, F. (2015). The impacts of socio-economic factors on migration across Turkish regions: A spatial data analysis, Emc Review, 10(2), 194-210. https://doi.org/10.7251/EMC1502194O
Özgür, E. M. (2001). Türkiye Coğrafyası, Ankara: Hilmi Usta Matbaacilik.

Öztürk, M., Topaloğlu, B., Hilton A., \& Jongerden J. (2017). Rural-urban mobilities in Turkey: socio-spatial perspectives on migration and return movements, Journal of Balkan and Near Eastern Studies, 20(5), 513530, https://doi.org/10.1080/19448953.2018.1406696

Ryan, L. (2011). Migrants' social networks and weak ties: accessing resources and constructing relationships post-migration. The SociologicalReview, 59(4), 707-724.https://doi.org/10.1111/j.1467954X.2011.02030.x

Sarı, V. İ. ve Kındap, A. (2018). Türkiye'de kentsel yaşam kalitesi göstergelerinin analizi. Journal of Turkish Court of Accounts/ Sayistay Dergisi, 108, 39-72.

Sanayi ve Teknoloji Bakanlığı (2019). Illerin ve bölgelerin sosyoekonomik gelişmişlik sıralaması araştırması (SEGE-2017), Kalkınma Ajansları Genel Müdürlüğü, Ankara.

Stouffer, S. A. (1940). Intervening opportunities: a theory relating mobility and distance, American sociological review, 5(6), 845867. https://www.jstor.org/stable/2084520

Tandoğan, A. (1998). Demografik temel kavramlar ve Türkiye nüfusu. Trabzon: Eser Ofset.

Timor, A. (1997). Orta büyüklükteki şehirler ve taşıdıkları önem. İstanbul Üniversitesi Coğrafya Dergisi, 5, 83-101.

Turut, H. ve Özgür, E. M. (2018). Bir kente göçün hikâyesi: süreçler, bütünleşme ve aidiyet, Coğrafi Bilimler Dergisi, 16(1), 153-180.

TÜİK, İller arası göç verileri, https://biruni.tuik.gov.tr/medas/?kn $=95 \&$ locale $=\operatorname{tr}$

TÜİK, İllerde yaşam endeksi, http://www.tuik.gov.tr/PreTablo.do?alt $\mathrm{id}=1106$

TÜİK, Nüfus ve Konut Araştırmas1, http://www.tuik.gov.tr/PreHaber Bultenleri.do?id $=15843$

Tümertekin, E. ve Özgüç N. (2015). Beşeri Coğrafya: İnsan, Kültür, Mekân, İstanbul: Çantay Kitapevi.

Tümertekin, E. ve Özgüç, N. (1997). İstanbul'da nüfusun doğum yerlerine göre dağılışı, İstanbul İnsan ve Mekân içinde (s. 237-269), İstanbul: Tarih Vakfi Yurt Yayınları.

Ünal, Ç. (2020). İzmir'in göç analizi, Doğu Coğrafya Dergisi, 25(43), 195-208.

Walters, W. H. (2000). Assessing the impact of place characteristics on human migration: the importance of migrants' intentions and enabling attributes. Area, 32(1), 119-123. https://www.jstor.org/ stable/20004043

Yakar, M. (2013). Türkiye'de iller arası net göçlerle sosyo-ekonomik gelişmişlik arasındaki ilişsinin coğrafi ağırlıklı regresyon ile analizi. Ege Coğrafya Dergisi, 22(1), 27-44.

Yakar, M. ve Sert Eteman, F. (2017). Türkiye'de iller arası göçlerin nodexl ile sosyal ağ analizi. Göç Dergisi, 4(1), 82-109.

Yakar, M., Saraçl1, S. ve Yazıcı, H. (2010). Afyonkarahisar ilinde iller aras1 göçlerin gelişmişlik endeksleriyle analizi. Doğu Coğrafya Dergisi, 15(24), 255-271. 
